\title{
Adoption Level of Bio-pesticides by Brinjal Growers in Bulandshahr District of Western Uttar Pradesh, India
}

\author{
A.S. Maurya ${ }^{1 *}$, R.N. Yadav $^{1}$, Sarju Narain ${ }^{2}$, Prerana Kaushal ${ }^{3}$ and Kshitij Parmar ${ }^{1}$ \\ ${ }^{1}$ Department of Agricultural Extension and Communication, SVPUAandT, Modipuram, \\ Meerut-250110, (U.P.), India \\ ${ }^{2}$ Department of Agricultural Extension, B.N.P.G. College, Rath, Hamirpur, (U.P), India \\ ${ }^{3}$ Department of Home Science Extension, BHU, Varanasi, (U.P.)-251001, India \\ *Corresponding author
}

\begin{tabular}{|c|c|}
\hline \multicolumn{2}{|r|}{ A B S T R A C T } \\
\hline & \multirow{7}{*}{$\begin{array}{l}\text { The present investigation was carried out during the year } 2016-17 \text { in Bulandshahr district } \\
\text { of Western Uttar Pradesh to assess the adoption level of bio-pesticides by brinjal growers } \\
\text { in brinjal production. Bulandshahr district comprise of } 16 \text { blocks in which two blocks } \\
\text { namely Lakhoti and Jahangirabad were purposively selected. Four villages namely } \\
\text { Dhakka, Dhakroli from lakhoti block and Shekhpur, Pasoli selected from Jahangirabad } \\
\text { block. From the selected each village's } 20 \text { respondents were selected randomly, thus a total } \\
\text { of } 80 \text { brinjal growers constituted the sample size for the study and data were collected by } \\
\text { means of personal interview with the help of pre structured schedule. The study find out } \\
\text { that brinjal growers of selected areas were not having proper adoption of bio-pesticides in } \\
\text { brinjal production. They were medium level of adoption to summer deep ploughing while } \\
\text { they were have low level of adoption of soil treatment, seed treatment, foliage spray in } \\
\text { standing crop, light/pheromone traps and bio-agents related practices regarding bio- } \\
\text { pesticides. Findings also shows large gap between recommendation and adoption in } \\
\text { respect to bio-pesticides. So, it is an argent need of skill oriented training to brinjal } \\
\text { growers regarding bio-pesticides for higher and safer brinjal production. }\end{array}$} \\
\hline Keywords & \\
\hline Bio-p & \\
\hline $\begin{array}{l}\text { Adoption, Brinjal, } \\
\text { Brinjal growers. }\end{array}$ & \\
\hline Article Info & \\
\hline $\begin{array}{l}\text { Accepted: } \\
\text { 23 September } 2017 \\
\text { Available Online: } \\
10 \text { October } 2017\end{array}$ & \\
\hline & \\
\hline
\end{tabular}

\section{Introduction}

Brinjal (Solanum melongena L.) is one of the important and popular vegetable and plays animportant role in balance nutrition. It is amazing to record that eggplant possesses the highest nutritive value, providing energy of $24 \mathrm{Cal}$. The brinjal fruit contains moisture $(96 \%)$, protein $(1.4$ g.), fat $(0.3$ g.) carbohydrates (4 g.), and fibre (1.3 g.) are found in $100 \mathrm{gm}$. of fruit. Besides these, various essential minerals and vitamins viz., calcium (18 mg.), phosphorus (47 mg.), iron

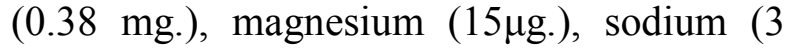

mg.), chromium (0.07 mg.), sulphur (44 mg.), Carotene (74 mg.), Riboflavin (0.11 mg.), Thiamin (0.03 mg.), Niacin (0.9 mg.), Folic acid (5 mg.), total folic acid (34 mg.), vitamin C (1.2 mg.) and Chlorine (52 mg.) are found (Anonymous, 2015). From nursery phase to ripening of brinjal fruit it infected by several types of insect pests and diseases, where insect pest also cause great losses of output and quality also. For minimizing losses and to increase the profitability, farmers generally use chemical pesticides, especially by better 
endowed farmers in case of commercial crops like brinjal.

India is the largest producer of pesticides in Asia and ranks $12^{\text {th }}$ in world for application of pesticides. Despite their enormous benefits the unregulated and indiscriminate application of chemical pesticides has raised serious concerns about environment and human health, contamination of surface water, reducing beneficial micro-organism and quality of nutritive food materials, harmful effects on birds and other wildlife etc.

So minimize the hazards of chemical pesticides with their regulated and controlled application as well as focuses on the importance and application of bio-pesticides and Integrated Pest Management for sustainable development in Indian Agriculture (Bhardwaj and Sharma, 2013).

\section{Materials and Methods}

This study was conducted in Bulandshahr district of Western Uttar Pradesh during the year 2016-17. Bulandshahr district comprise of 16 blocks in which two blocks namely Lakhoti and Jahangirabad were purposively selected.

Two villages selected from each blocks. From the selected each village's 20 respondents were selected randomly, thus a total of 80 brinjal growers constituted the sample size for the study. The data were collected through personal interview with the help of pre structured schedule. The data were analysed and find out the percentage and rank order.

\section{Results and Discussion}

The adoption process is the mental process through which an individual passes from first hearing of an innovation to its final adoption, while adoption is a decision to continue the full use of an innovation. Generally, the farmers do not adopt package of practices fully. There is only a partial adoption by them. As a result, the gap always appears between the recommended production technology and their use at farmer's field. With a view to find out the extent of adoption of recommended practices of bio-pesticides using in brinjal production, the brinjal growers were asked to give information about practices of bio-pesticides adopted by them.

Reddy and Reddy (1998) found that variables such as farm power, farm size, contact with extension agency, pests and disease management, achievement motivation, scientific orientation and risk preference were positively and significantly associated with adoption level of the contact farmers. The data regarding extent of adoption are given in Table.

It is evident from Table 1 that maximum nom. of respondents 91.25\%, 93.75\%, 83.75\%, $81.25 \%$ and $96.25 \%$ belonged from low level of adoption category about the soil treatment, seed treatment, foliage spray in standing crop, light trap and pheromone traps, bio-agents, respectively and $46.25 \%$ respondents found under the medium level of adoption about summer deep ploughing in measurement of fruit and shoot borer in brinjal production.

The data of the Table 2 shows that most of respondents $83.75 \%, 81.25 \%$ and $100 \%$ belonged from low level of adoption category about the foliage spray of botanical biopesticides in standing crop, light trap and pheromone traps and bio-agents, respectively.

It was also found that $46.25 \%$ respondents found under the medium level of adoption about summer deep ploughing in measurement of jassid and aphids in brinjal production. 
Table.1 Distribution of the respondents regarding to adoption level of bio-pesticides for measurements of fruit and shoot borer in brinjal production

\begin{tabular}{|c|c|c|c|c|c|c|c|}
\hline \multirow{2}{*}{ S. No. } & Protection measures & \multicolumn{3}{|c|}{ Adoption level } \\
\cline { 3 - 8 } & & \multicolumn{2}{|c|}{ Low } & \multicolumn{2}{c|}{ Medium } & \multicolumn{2}{c|}{ High } \\
\cline { 3 - 9 } & & F & P & F & P & F & P \\
\hline 1. & Summer deep ploughing & 28 & 35.00 & 37 & 46.25 & 15 & 18.75 \\
\hline 2. & Soil treatment & 73 & 91.25 & 07 & 08.75 & 00 & 00.00 \\
\hline $\mathbf{3 .}$ & Seed treatment & 75 & 93.75 & 05 & 06.25 & 00 & 00.00 \\
\hline $\mathbf{4 .}$ & Standing crop & & & & & & \\
\hline & Botanical bio-pesticides & 67 & 83.75 & 13 & 16.25 & 00 & 00.00 \\
\hline & Traps & 65 & 81.25 & 15 & 18.75 & 00 & 00.00 \\
\hline & Bio-agents & 77 & 96.25 & 03 & 03.75 & 00 & 00.00 \\
\hline
\end{tabular}

$\mathrm{F}=$ Frequency, $\mathrm{P}=$ Percentage

Table.2 Distribution of the respondents according to adoption level of bio-pesticides in measurements of jassid and aphids in brinjal production

\begin{tabular}{|c|c|c|c|c|c|c|c|}
\hline \multirow[t]{3}{*}{ S. No. } & \multirow[t]{3}{*}{ Protection measures } & \multicolumn{6}{|c|}{ Adoption level } \\
\hline & & \multicolumn{2}{|c|}{ Low } & \multicolumn{2}{|c|}{ Medium } & \multicolumn{2}{|c|}{ High } \\
\hline & & $\mathbf{F}$ & $\mathbf{P}$ & $\mathbf{F}$ & $\mathbf{P}$ & $\mathbf{F}$ & $\mathbf{P}$ \\
\hline 1. & Summer deep ploughing & 28 & 35.00 & 37 & 46.25 & 15 & 18.75 \\
\hline 2. & In standing crop & & & & & & \\
\hline$\bullet$ & $\begin{array}{l}\text { Botanical bio-pesticides } \\
\text { (Neem based, Garlic } \\
\text { extract, Tobacco extract) }\end{array}$ & 67 & 83.75 & 13 & 16.25 & 00 & 00.00 \\
\hline$\bullet$ & $\begin{array}{l}\text { Light traps/Pheromone } \\
\text { traps }\end{array}$ & 65 & 81.25 & 15 & 18.75 & 00 & 00.00 \\
\hline$\bullet$ & Bio-agents & 80 & 100.00 & 00 & 00.00 & 00 & 00.00 \\
\hline
\end{tabular}

$\mathrm{F}=$ Frequency, $\mathrm{P}=$ Percentage

Table.3 Distribution of the respondents according to adoption level of bio-pesticides in measurements of whitefly in brinjal production

\begin{tabular}{|c|c|c|c|c|c|c|c|}
\hline \multirow{2}{*}{ S. No. } & Protection measures & \multicolumn{9}{|c|}{ Adoption level } \\
\cline { 3 - 8 } & & \multicolumn{2}{|c|}{ Low } & \multicolumn{2}{c|}{ Medium } & \multicolumn{2}{c|}{ High } \\
\cline { 3 - 8 } & & F & P & F & P & F & P \\
\hline $\mathbf{1 .}$ & Summer deep ploughing & 30 & 37.50 & 36 & 45.00 & 14 & 17.50 \\
\hline $\mathbf{2 .}$ & In standing crop & & & & & & \\
\hline - & $\begin{array}{c}\text { Botanical bio-pesticides } \\
\text { (Neem based, Garlic } \\
\text { extract, Tobacco extract) }\end{array}$ & 62 & 77.50 & 18 & 22.50 & 00 & 00.00 \\
\hline & $\begin{array}{c}\text { Light traps/ Pheromone } \\
\text { traps }\end{array}$ & 67 & 83.75 & 13 & 16.25 & 00 & 00.00 \\
\hline
\end{tabular}

$\mathrm{F}=$ Frequency, $\mathrm{P}=$ Percentage 
Table.4 Distribution of the respondents according to use of chemical pesticides as substitute of bio-pesticides

\begin{tabular}{|c|c|c|c|c|c|}
\hline S. No & Statements & \multicolumn{2}{|c|}{ Yes } & \multicolumn{2}{|c|}{ No } \\
\cline { 3 - 6 } & & F & P & F & P \\
\hline $\mathbf{1 .}$ & $\begin{array}{c}\text { Do you use chemical pesticide as } \\
\text { substitute of bio-pesticides? }\end{array}$ & 80 & 100.00 & 00 & 00.00 \\
\hline
\end{tabular}

The data of the Table 3 observed that most of respondents $77.50 \%$ and $83.75 \%$ belonged from low level of adoption category about the foliage spray of botanical bio-pesticides in standing crop and use of light and pheromone traps, respectively in measurement of whitefly.

It was also found that $45.00 \%$ respondents found under the medium level of adoption about summer deep ploughing in measurement of whitefly in brinjal production.

It is evident from Table 4 that 100.00 per cent respondents were using the chemical pesticides as the substitute of bio-pesticides for the measurements of fruit and shoot borer, jassid and aphids and white fly in brinjal production.

It is concluded that majority of the respondents belonged to low level category of adoption of different practices related to biopesticides and its application by brinjal growers in brinjal production for the measurements of fruit and shoot borer, jassid and aphids and white fly in brinjal production.

\section{Acknowledgement}

Author is thankful to Dr. R. N. Yadav, Professor, Department of Agricultural Extension and Communication, SVP University of Agriculture and Technology, Modipuram, Meerut-250110, U.P., India for his kind of guidance, motivation and unconditional support for this work.

\section{References}

Anonymous, 2015. Food and Agriculture Organization Database.

Bhardwaj, Tulsi and Sharma, J. P. 2013. Impact of pesticides application in agricultural industry: An Indian scenario. International Journal of Agriculture and Food Science Technology. Volume 4(8): 817-822.

Maisnam, G., and Singh, M. K. 2015. Analysis on extent of adoption of recommended Rabi Vegetable Cultivation Practices. Indian Journal of Applied Research, 5 (5):19-21.

Mou, Moushumi Mobarak 2017. Adoption of improved vegetable cultivation practices by the farmers in selected areas of Shajahanpurupzila under Bogradistrict. Thesis, M.Sc. (Agricultural Extension and Information System), Sher-e-Bangla Agricultural University, Dhaka.

Patel, G. R., Patel, N. K. and Patel, G. D. 2015. Adoption of new production technology of tomato in Navsari district of south Gujarat. Journal of Science; Vol.-5/ Issue 12/2015: 1305-1308.

Sachin Kumar, Singh, Dan, Yadav, R. N., Singh, V. K., R. P. and Nazim Ali 2010. Assessment of adoption level of potato growers and their adoption gap in potato production technology. 28 (1B): 664-66. Singh, D.K., Singh, B. K., Yadav, V. P. and Singh, Lotan 2010. Adoption behaviour of commercial vegetable growers in district Ghaziabad (UP).Indian Res. J. 
Ext. Edu.10 (3), pp 5-9. September, 2010.

Singh, P. K., Barman, K. K., and Varshney, J. G. 2011. Adoption behaviour of vegetable growers towards improved technologies. Indian Research Journal of Extension Education; 11(1): 62-65.
Suman, R.S., 2014. Knowledge and adoption of cabbage management practices by farmers. Journal of Agricultural Extension and Rural Development, 6 (3):115-117.

\section{How to cite this article:}

Maurya, A.S., R.N. Yadav, Sarju Narain, Prerana Kaushal and Kshitij Parmar. 2017. Adoption Level of Bio-pesticides by Brinjal Growers in Bulandshahr District of Western Uttar Pradesh. Int.J.Curr.Microbiol.App.Sci. 6(10): 2642-2646. doi: https://doi.org/10.20546/ijcmas.2017.610.312 